\title{
Attitudes of accounting students towards ethics, continuous professional development and lifelong learning
}

Gideon Els

\begin{abstract}
With a myriad of corporate scandals involving fraud and theft across the world, the auditing profession has been put under the spotlight with the prominence of promoting an ethical attitude within the profession and amongst its members. By way of an empirical study conducted with a group of students at a leading university in South Africa, it was found that the necessity for change and CPD are concepts not collectively agreed upon by all within the profession, even more so when it comes to a group of final-year undergraduate students at this university. This article provides a series of recommendations regarding the improvement of the current teaching and learning model in order to include a CPD approach when it comes to ethics.
\end{abstract}

Key words: continuous professional development, lifelong learning, ethics, Professional Accountants, accounting education

\section{Introduction}

Rapid change has been the predominant characteristic of the professional environment in which Chartered Accountants have been operating for the past few years (Nelson, 1995). These days, a programme of accounting education and experience that leads an undergraduate student to become a qualified Chartered or Professional ${ }^{1}$ Accountant needs to go beyond the traditional approach, which emphasised 'transfer of knowledge', or learning defined and measured strictly in terms of knowledge of principles, standards, concepts, facts and procedures at any given time. Society also demands continued ${ }^{2}$ professional accountability of Chartered Accountants in an era of exponential knowledge proliferation and technological change (Houle, 1980; Cavanaugh, 1993).

The viability of accountancy as a profession depends on the ability and willingness of its individual members to accept responsibility for meeting these continuous professional developmental challenges. To meet these, the profession needs to ensure that individuals becoming Chartered Accountants achieve an agreed level of competence, which is then maintained in the foreseeable future. Grimstad (1964) echoed this sentiment, stating that no profession can continue to be effective unless there is an adherence to a high standard of ethical conduct.

Dr Gideon Els is Associate Professor and Head of the Department of Finance and Investment Management at the University of Johannesburg, South Africa. Although his main research focus is in Higher Education, he has a keen interest in Applied Ethics and Business Ethics research.
The means by which individuals obtain competence are education, self-learning and experience and by engaging in continuous professional development (CPD) (Clark, 1980; International Federation of Accountants (IFAC), 2003a).

Lifelong learning has emerged as one of the major challenges for the worldwide knowledge society of the future (Fischer \& Scharff, 1998), and the continuous development of professional competence and lifelong learning are critical if the Chartered Accountant is to meet the standard expectations set by the profession, employers and the general public.

As part of research conducted at a leading South African residential university, it was found that the necessity for change and CPD are concepts not collectively agreed upon by all within the accounting profession. Moreover, this is true when it comes to a group of final-year undergraduate students at this university.

This article will point out possible deficiencies in the current teaching and learning model used at a Higher Education institution, and is based on the results of an empirical study using a comprehensive survey as well as an analytical comparison of the aims set by the professional body. The article will conclude by providing a series of recommendations as regards the improvement of the current teaching and learning model implemented in the education and training of prospective Chartered Accountants in an attempt to include a clearer CPD approach when it comes to business ethics.

\section{The importance of change in accounting education}

The research, on which this article is based, comprised an empirical study of the attitudes of a group of final-year undergraduate accounting students at a residential South African university with regard to their perception of change and of the core values of a Chartered Accountant within the profession. With an increased call for the utilisation of an integrated and inclusive approach to undergraduate accounting teaching and the need for CPD amongst Chartered Accountants, the study also examined the students' attitude toward change and the necessity of CPD for Chartered Accountants.

Universities in South Africa, accredited by the South African Institute of Chartered Accountants (SAICA) as training institutions for Chartered Accountants, struggle with change. This includes change with a focus on $\mathrm{CPD}$, change with regard to the integration of ethics in the curriculum, and change to deliver more chartered 
accounting candidates from previously disadvantaged backgrounds thereby reflecting a more diverse sample of the South African population.

Over the past 15 years, there has been mounting criticism of accounting education. A number of reports and articles (Albrecht \& Sack, 2001; Person, 2002; Diller-Haas, 2004) criticise the way Higher Education institutions teach students accounting. Several authors such as Sundem, Williams and Chironna (1990), Lovell (1992), May, Windall and Sylvestre (1995), Adler and Milne (1997a, 1997b) all address the lack of lifelong and self-directed learning skills that professional accounting graduates should possess for success in the profession. The need for improved problem-solving, teamwork, communication and interpersonal skills are issues raised in a number of the reports and by certain authors (Milne \& McConnell, 2001).

Bedford and Shenkir (1987:86) stressed the shortcomings of accounting education in the following scathing indictment: 'Despite widespread complaints that accounting graduates do not know how to communicate, do not reason logically, are deficient in inter-personal skills, and cannot think creatively and responsibly, university education has persisted in teaching the content of textbooks rather than developing students' capabilities.' This notion was also carried by a study done by Dempsey and Stegmann (2001) at a South African university.

Recently, this negative notion has however changed. According to data compiled by the American Institute of Certified Public Accountants (in Myers, 2005), undergraduate students opting for studies to become Professional Accountants within the United States of America have increased by 6\% from 2001 to 2002. Myers (2005) also found that changes may have occurred (even unnoticed) and accounting students coming from higher education institutions '... are smarter [and] better educated today ...'.

Educators delivering professional accounting education programmes will however need to respond to the changing needs of the international accountancy profession, as well as the needs of the individual Chartered Accountants (IFAC, 2003a) by providing students with the tools for development and learning after qualification. Maintaining professional competence in the face of increasing change makes it imperative that accountants develop and preserve an attitude of learning to learn. The education and training of Professional Accountants should provide a foundation of knowledge, skills and professional values that will enable them to continue to learn and adapt to change throughout their professional lives (SAICA, 2005a; 2005b).

The goal of accounting education and training at Higher Education institutions should be to produce competent Professional Accountants who make a positive contribution to the profession and to the society in which they work over their lifetimes. Candy, Crebert and O'Leary (1994) and Candy (1995) however see universities cramming their undergraduate programmes (also undergraduate chartered accounting programmes) with technical content at the expense of broader and more general aims, including lifelong learning.

Far too many learners, educationalists argue, conceive learning as reproducing (acquiring facts and memorising) rather than as making sense (understanding relationships). Far too many learners also believe teachers are responsible for their learning: teachers select the content, present it and test whether it has 'stuck', rather than learners being responsible for their own learning (Gibbs, 1992; Milne \& McConnell, 2001).

\section{Changes in accounting education}

IFAC (2003a) determined a scope of international education standards, which is intended to advance the accountancy profession by establishing benchmarks for the minimum learning requirements of qualified Chartered Accountants. Even though IFAC notes that member bodies have an obligation to their current and future members to ensure that members have a continuing understanding of professional values, ethics and attitudes, they utilise the Educational Standard IES 4 Professional Values, Ethics and Attitudes (IFAC, 2003a) to lay a foundation for member bodies as regards ethics within the profession.

What follows is a discussion of the important changes within the education and training environment of the accounting profession with regard to the integrated learning approach to ethics as well as the issues of lifelong learning and continuous professional development.

\section{An integrated learning approach with regard to ethics}

Various authors (e.g. Carlson and Burke (1998), Baetz and Carson (1999) and Maclagan (2002)) have been at the forefront of the ongoing debate regarding the teaching of Business Ethics within a Higher Education milieu.

If future Chartered Accountants are to experience professional values, ethics and attitudes as important to their work, it is essential that they do not perceive the treatment of professional values, ethics and attitudes as peripheral to their main education programmes. IFAC's Educational Standard IES 2, Content of Professional Education Programmes, agrees with this notion and states, 'Professional values, ethics and attitudes, however, run through all areas and may be integrated with many of the other subjects' (IFAC, 2003a:30).

This is contrary to what Grimstad (1964) proclaimed in his article, which suggested that accounting [business] ethics could be taught in each accounting course in an accounting programme or possibly in a separate course. 
Recently, issues relating to the teaching of Business Ethics seem to have evolved from questions of 'Should ethics be taught to students?' to questions of 'How should ethics be taught to students?' (Wright, Cullinan \& Bline, 1998).

It is now accepted that the teaching of Business Ethics has become a core part of undergraduate curricula across the world (Kenny \& Eining, 1996; Cragg, 1997). Within the Higher Education context, the importance of ethics education is increasingly recognised because knowledge alone is no guarantee of moral character (Prozesky, 2001; Cowton \& Cummins, 2003).

The approach of teaching Ethics in isolation appears to have a limited effect on the moral development of accounting students. In studies conducted by St. Pierre, Nelson and Gabbin (1990) as well as Shaub (1991), it was found that, while ethical awareness and reasoning skills tend to improve after taking Ethics as a separate course, the effects appear to be short term by nature. IFAC even stated, '... values education suffers most when it is separated from reality and taught as a dry, selfcontained topic. A well-planned programme, especially integrated with work experience, can handle the topic very effectively' (IFAC, 1998:18).

Recent accounting research suggests that ethics training might affect the process by which accounting students and accountants resolve ethical dilemmas (Hiltebeitel \& Jones, 1991; Prozesky, 2001). For this reason, many academics see the teaching of Business Ethics as an integrated approach rather than as a subject in a vacuum (Kenny \& Eining, 1996; Nelson \& Wittmer, 2001; Sims, 2002; Sims \& Brinkmann, 2003).

Loeb $(1988,1990)$ as well as Langenderfer and Rockness (1989) all gave ideas on how to resolve the contentious issue of teaching ethics to accounting students. They investigated whether Ethics should be taught as a separate course or be integrated with the rest of the curriculum. Josephs (1978) argues that an emphasis on the interdisciplinary acquisition of knowledge will better prepare students for practice. Therefore, undergraduate programmes should strive to achieve the outcome of a professional who is able to recognise and address a wide range of business issues in a changing context.

Even though the integrated approach to the teaching of Ethics has been high on the academic agendas of many universities across the world, it certainly did not guarantee an automatic change. Based on a study by Grasso and Kaplan (1998), which dealt with ethics and taxation, reasons were given for the failure of proper integration of ethics in taxation that included:

- the large amount of technical detail that has to be covered within the [prescribed] curriculum;

- the lack of ethics training for the educators; and

- the effectiveness of ethics coverage within the curriculum.
University educators involved in teaching Business Ethics frequently take a detached, non-committal moral stance when discussing the moral quality of various moral perspectives (Cragg, 1997). Various other concerns or obstacles were identified (Els, 2007) and include inter alia the relevancy of the course for the students, the lack of effective integration of ethics content into the full curriculum due to teachers not feeling qualified or confident to teach ethics, and the quality (or lack thereof) of the materials used in these ethics courses.

\section{Lifelong learning}

Admission to membership of an IFAC member body is recognition that a person is deemed to have met the requirements for qualification as a Chartered Accountant. In a time of continuous change, however, development of professional competence (IFAC, 2003b) and lifelong learning (IFAC, 2004) is critical to meet the needs of the users of a changing professional environment (IFAC, 2003a).

Learning to learn involves developing skills and strategies that help individuals to learn more effectively and to use these effective learning strategies to continue to learn throughout life. This process results from, leads to, and enhances a questioning spirit and a lifelong desire to learn. Competence is therefore not a static term, but evolves over a lifetime of learning.

In most current accounting curricula, competence is defined and measured in terms of knowledge of principles, standards, concepts and facts as published by professional bodies or regulatory agencies. This 'transfer of a body of knowledge' approach to education has been the traditional focus of accounting education, with the result that the 'accumulation of knowledge' approach is no longer adequate (IFAC, 2003c). The focus of accounting education should change from mere knowledge acquisition and accumulation to a focus based on a 'learning to learn' approach - a lifelong learning approach.

Achieving the goal of providing a foundation for lifelong learning requires a thorough grounding in the professional knowledge, skills and values, ethics and attitudes essential for professional competency (IFAC, 2003a). It is furthermore an attempt to provide potential Chartered Accountants with a framework for exercising professional judgement and for acting in an ethical manner that is in the best interest of society and the profession.

\section{Continuous professional development (CPD)}

The process of lifelong learning commences early and continues throughout the individual's career. CPD may therefore be seen as an extension of the education programme leading to qualification as a Chartered Accountant (IFAC, 2003a; IFAC, 2004). 
IFAC Educational Standard IES 7, Continuing professional development (IFAC, 2004), is based on the principle that it is the responsibility of the individual Chartered Accountant to develop and maintain the professional competence necessary to provide high-quality services to clients, employers and other stakeholders. 'Continued professional development is an extension of the learning process leading to qualification as a Chartered Accountant, where the professional knowledge, professional skills and professional values, ethics and attitudes gained continue to develop and are refined and appropriate for the professional activities and responsibilities of the individual' (IFAC, 2004:3).

It is interesting to note that IFAC sees continued professional development as something aimed at the post-qualification development and maintenance of professional competence. SAICA (2005a) is however of the opinion that this process should start during the pre-qualification education and training process (at the undergraduate level) and should continue after qualification. SAICA feels that Higher Education institutions should encourage the development of lifelong learning by, inter alia, making learners take responsibility for their own learning and become active participants in the learning process (SAICA, 2005a).

Cavanaugh (1993:114) notes that, in practice, professionals acquire much more learning from readings, discussions with colleagues and experience than through formal classroom training. Therefore, focusing on outcomes, she feels that educators should '... help students develop an effective system for learning that will facilitate their transition from education to practice'.

When the Chartered Accountant recognises that learning is necessary or desired, the individual will need to determine what is to be learned, how best to learn it and how well it is to be learned. 'This essentially means that continuous professional learning needs to be selfdirected' (Williams, 2001:2). The learning activity of the student therefore needs to change - from an educator telling one what, where and when to learn to the student making these decisions.

\section{Empirical study}

In order to provide adequate answers to the research problem, the perceptions of a group of final-year undergraduate students with regard to change and the core values of a Chartered Accountant within the profession study were empirically investigated. For this empirical study, the researcher decided on the use of a research questionnaire as a measurement instrument. A detailed and comprehensive questionnaire utilising a quantitative research design was therefore developed.

The questionnaire comprised six sections of which three are important for this article: (i) students' background information; (ii) perceived core values within the Chartered Accountant profession; and (iii) change and the necessity of continued professional development for Chartered Accountants.

The condition of reliability and validity for quality of measurement were also taken into consideration. Reliability demonstrates the consistency of measurement (Bryman \& Cramer, 1997), which means that with repeated measurements, equivalent results should be found.

For this research the issue of equivalence reliability was of great concern, as multiple indicators were used. Equivalence reliability can be measured by using item analysis. With this test, the response to each item versus the response to all the items in the questionnaire is measured. The coefficient of reliability (Cronbach's alpha or $\alpha$ ) must be at least 0.7 or higher to be reliable (Bryman \& Cramer, 1997).

Validity is the degree to which the measuring instrument actually measures what it is supposed to measure (Uys, 2003). For this a process known as factor analysis was used to determine construct validity.

Factor analysis was 'designed' nearly 100 years ago by psychologist Charles Spearman, who hypothesised that the enormous variety of tests of mental ability measures of mathematical skill, vocabulary, other verbal skills, artistic skills, logical reasoning ability, etc. - could all be explained by one underlying factor of general intelligence, which he called $g$ (Williams, Zimmerman, Zumbo \& Ross, 2003:114).

The validity of a sample depends on two considerations, namely accuracy and precision. Accuracy is the degree to which bias is absent from a sample (Cooper \& Schindler, 2003). Precision refers to whether a question posed to a respondent, for example, asks what the researcher wants and needs to know (Cooper \& Schindler, 2003).

For the empirical analysis, pre-tested and adjusted questionnaires consisting of ordinal and interval variables were collected from a combined final-year accounting class at the beginning of their second semester at the University of Johannesburg, South Africa.

The University of Johannesburg is regarded as the residential leader in the education and training of Chartered Accountants in South Africa. For the past five years, candidates from this university writing the qualifying examination for Chartered Accountants attained averages exceeding that of the rest of the country by far.

The non-probability sampling approach known as judgement or purposive sampling was used where the author selected a sample to conform to the criterion that all students had to be in their final or third year of study with Accounting, Auditing, Financial Management and Taxation as major subjects.

The sample size $(n)$ was 494 respondents out of a population of 503. In the next section of this article, the results of the empirical study are given in tabular format. 


\section{Analysis and results}

\section{Perceived core values}

In this section of the questionnaire, respondents had to express their opinion on certain core values pertaining to Chartered Accountants and the profession (see Table 1) by making use of a 4-point Likert scale where: not important $=1$; somewhat important $=2$; important $=3$; and very important $=4$.

Table 1 provides the applicable descriptive statistics for this section where the mean response (in ascending order) and standard deviation to the items are provided.

Table 1: Frequency distribution of the PerCeived core Values of a Chartered Accountant $(N=494)$

\begin{tabular}{lcccccc}
\hline \multirow{2}{*}{$\begin{array}{l}\text { How important is it for a } \\
\text { Chartered Accountant to: }\end{array}$} & Mean & \multirow{2}{*}{$\begin{array}{c}\text { Standard } \\
\text { deviation }\end{array}$} & \multicolumn{4}{c}{ Percentiles } \\
\cline { 3 - 8 } & & $\mathbf{2 5}$ & $\mathbf{5 0}$ & $\mathbf{7 5}$ & $\mathbf{9 5}$ \\
\hline be trustworthy? & 3.65 & 0.779 & 4 & 4 & 4 & 4 \\
\hline be reliable? & 3.63 & 0.796 & 4 & 4 & 4 & 4 \\
\hline show integrity? & 3.62 & 0.803 & 4 & 4 & 4 & 4 \\
\hline have professional competence? & 3.56 & 0.794 & 3 & 4 & 4 & 4 \\
\hline have high ethical standards? & 3.56 & 0.822 & 3 & 4 & 4 & 4 \\
\hline $\begin{array}{l}\text { acquire the skill of continuous } \\
\text { professional development? }\end{array}$ & 3.34 & 0.798 & 3 & 4 & 4 & 4 \\
\hline be a life-long learner? & 3.18 & 0.827 & 3 & 4 & 4 & 4 \\
\hline
\end{tabular}

When one takes into account that $95 \%$ and above of the values were indicated as 4 (i.e. very important), it is apparent from Table 1 that respondents felt that Chartered Accountants need certain core values. When one focuses only on the mean responses, it is interesting that the skills of 'lifelong learning' and 'continuous professional development' do not seem to be very important, compared to the others, as they have the lowest mean response values. Acquiring the skill of continuous professional development has a mean response of $3.34(n=491)$ and that of lifelong learning a mean response of $3.18(n=$ 490). The value of 'trustworthiness' seems to be the most important value with a mean response of $3.65(n=491)$.

\section{Change and the necessity of continued professional development for Chartered Accountants}

Exploratory factor analysis was performed on Section 3 of the questionnaire (change and CPD) for the complete sample $(n=494)$, using SPSS 14.0 for Windows with orthogonal varimax rotation and Kaizer normalisation to identify the various dimensions of change and the necessity of continued professional development for Chartered Accountants. Thirty-nine items from Section 3 of the questionnaire were included in the first step of the analysis. After eliminating two items due to a low correlation with other items that belong to the same factor, 37 items were retained in eight factors, explaining 52.076 percent of the information.

Item analysis and individual reliability tests then decreased the number of factors to four by only selecting those with $\alpha>0.7$ (see Table 2).

TABLE 2: FACTOR ANALYSIS

\begin{tabular}{lrll}
\hline$n$ & 484 & & \\
KMO & 0.913 & & \\
$p<0.05$ & 0.000 & & \\
Eigen values & 1.389 & & \\
Percentage variance & 32.812 & & 0.752 \\
Factor 1: CPD & & Factor 2: Change & 0.761 \\
Alpha & 0.782 & Alpha & 0.718 \\
Standardised alpha & 0.786 & Standardised alpha & 0.720 \\
\hline Factor 3: Ethics & & Factor 4: LLL & \\
Alpha & 0.779 & Alpha & \\
Standardised alpha & 0.790 & Standardised alpha &
\end{tabular}

The four factors identified were:

- continuous professional development of Chartered Accountants (CPD);

- change with regard to the acquisition of skills and competencies by Chartered Accountants (Change);

- professional values, ethics and attitudes pertaining to Chartered Accountants (Ethics); and

- the approach to lifelong learning by Chartered Accountants (LLL).

Respondents had to indicate the extent to which they agreed or disagreed with various statements pertaining to these factors. Once again they had to use a 4-point Likert scale where: strongly agree $=1$; agree $=2$; disagree $=3$; and strongly disagree $=4$.

Table 3 provides the applicable descriptive statistics for this section where the mean response (in descending order) and standard deviation to the items are provided.

TAble 3: Frequency distribution of FaCtors

\begin{tabular}{|c|c|c|c|c|c|c|c|}
\hline Factors & $N$ & Minimum & Maximum & Mean & $\begin{array}{l}\text { Standard } \\
\text { deviation }\end{array}$ & Skewness & Kurtosis \\
\hline $\begin{array}{l}\text { Continuous professional development of Chartered } \\
\text { Accountants (CPD) }\end{array}$ & 494 & 1.00 & 2.88 & 1.7176 & 0.38245 & -0.190 & -0.527 \\
\hline $\begin{array}{l}\text { The approach to lifelong learning by Chartered Accountants } \\
\text { (LLL) }\end{array}$ & 494 & 1.00 & 3.00 & 1.5310 & 0.42081 & 0.511 & -0.180 \\
\hline $\begin{array}{l}\text { Change with regard to the acquisition of skills and } \\
\text { competencies by Chartered Accountants (Change) }\end{array}$ & 494 & 1.00 & 2.71 & 1.4540 & 0.36919 & 0.424 & -0.808 \\
\hline $\begin{array}{l}\text { Professional values, ethics and attitudes pertaining to } \\
\text { Chartered Accountants (Ethics) }\end{array}$ & 494 & 1.00 & 2.63 & 1.3727 & 0.31930 & 0.734 & -0.004 \\
\hline
\end{tabular}


Analysing the factor CPD (see Table 3) provided a mean response of $1.7176(n=494)$, which was also the highest of all four factors. This factor was also the only one that was negatively skewed with a mean value smaller than a median value. The median response of this factor was 2 (agree) with a $16.6 \%$ valid response rate $(n=82)$. These responses correspond well with the responses retrieved with regard to the core values (see previous section). The maximum response was 2.88 , which is very close to a 'disagree' response.

The fourth identified factor, LLL, had the second highest mean value of $1.5310(n=494)$, indicating a response somewhere between 'strongly agree' and 'agree'. It also had the largest standard deviation of all factors $(s=0.42081)$. These responses differ somewhat from what was found within the core values, but still indicate that the respondents felt that skills pertaining to lifelong learning are important.

Based on an analysis purely made up of means (in Table 3), the two remaining factors Ethics and Change seem to be more important than CPD and LLL. Both means $($ Ethics $=1.3727$; Change $=1.4540)(n=494)$ tend to be closer to a response of 'strongly agree' than just 'agree'. On an individual basis, it was found that 100 respondents, or $20.2 \%$, indicated a response of 'strongly agree' for the factor Change. A similar pattern was evident for the factor Ethics, where a valid response of $21.3 \%(n=105)$ was received for 'strongly agree'.

Contrasting the results with the objectives of this research provides for some interesting thoughts. One would have expected that final-year chartered accounting students would, to a large degree, have agreed that ethics training and continuous professional development are of the utmost importance when it comes to change within the chartered accounting profession.

Ethics and change within the profession seem to be important, whereas CPD and lifelong learning seem to be of less importance. If change is then so apparent within the profession and undergraduate students realise it is their responsibility to keep abreast of change by way of $\mathrm{CPD}$, why do these students not realise that change also affects the way they learn as part of their education and training but also once they are in practice? Why is it not possible to link the critical aspects of CPD with lifelong learning in an undergraduate curriculum?

\section{Conclusion and recommendation}

When analysing the perception of a group of final-year accounting students towards professional values, ethics and attitudes pertaining to Chartered Accountants, one may find that it corresponds well with students' perception with regard to the acquiring of skills and competency of Chartered Accountants. However, the same group of prospective Chartered Accountants do not have equally strong opinions when it comes to the issue of CPD and lifelong learning of Chartered Accountants.
Based on literature, this article pointed out that change, with regard to teaching method and content, needs to occur at an undergraduate level. Higher Education institutions need to acknowledge the important role they play in 'shaping young minds' and therefore need to the revisit their curricula. If today's Chartered Accountants need skills over and above mere theoretical knowledge, the general education of Chartered Accountants should provide a foundation for these, including a foundation of ethical values provided in such a manner that it cultivates a culture of lifelong learning coupled with CPD.

From an empirical study conducted amongst a group of 494 final-year undergraduate students at a leading South African university, it was noticeable that the responses (based on a 4-point Likert scale) in terms of the core values sought in Chartered Accountants tend to be between 3 (important) and 4 (very important). What was noticeable was that the core values of 'lifelong learning' and 'continuous professional development' received the lowest mean responses with the core value of 'trustworthiness' the highest.

Furthermore, exploratory factor analysis performed on 37 items dealing with change and CPD, provided the author with four factors where $\alpha>0.7$.

When analysing the 4-point Likert responses from the 494 respondents, it showed mean response values between 1 (strongly agree) and 2 (agree). Once again responses pertaining to the factors 'lifelong learning' and 'CPD' were marginally lower than that of 'change' and 'ethics', which is consistent with the analysis above. This may be attributable to the fact that these prospective Chartered Accountants still do not understand the importance of CPD and lifelong learning within their profession.

Even though CPD is something that Chartered Accountants will only engage in once they have qualified (i.e. after the 'education' phase), it is important that prospective Chartered Accountants become familiarised with the skills involved in practising CPD. If today's Chartered Accountants need skills other than mere theoretical knowledge, the general education of Chartered Accountants should provide a foundation for these, including a foundation of ethical values provided in such a manner that it cultivates a culture of lifelong learning coupled with CPD.

By integrating knowledge and skills across topics and disciplines, it may be possible to address multifaceted and complex situations typical of the change experienced in professional life, but at the same time also to stimulate undergraduate learners to value learning more when learning is integrated with the demands of their everyday professional life.

\section{Notes:}

1 The terms 'Chartered Accountant' and 'Professional Accountant' should be seen as interchangeable in this article. 
2 The terms 'continuous professional development' and 'continued professional development' should be seen as interchangeable in this article.

3 The terms 'ethics' and 'business ethics' should be seen as interchangeable in this article.

\section{References}

Adler, R.W. \& Milne, M.J. 1997a. Translating ideals into practice: An examination of international accounting bodies' calls for curriculum changes and New Zealand tertiary institutions; assessment methods. Accounting Education: An international journal, 6(2): 109-124.

Adler, R.W. \& Milne, M.J. 1997b. Improving the quality of accounting students' learning through action orientated learning tasks. Accounting Education: An international journal, 6(3): 191-215.

Albrecht, W.S. \& Sack, R.J. 2001. The perilous future of accounting education. The CPA Journal, 71(3): 16-23.

Baetz, M. \& Carson, A. 1999. Ethical dilemmas in teaching about ethical dilemmas: Obstacle or opportunity? Teaching Business Ethics, 3(1): 1-12.

Bedford, N.M. \& Shenkir, W.G. 1987. Reorienting accounting education. Journal of Accountancy, 164(2): 84-91.

Bryman, A. \& Cramer, D. 1997. Quantitative data analysis with SPSS for Windows. London: Routledge.

Candy, P.C. 1995. Developing lifelong learners through undergraduate education. In L. Summers (ed.) A focus on learning: Proceedings of the 4th Annual Teaching Learning Forum, Edith Cowan University, February 1995. Perth: Edith Cowan University. pp. ii-viii.

Candy, P.C., Crebert, G. \& O'Leary, J. 1994. Developing lifelong learners through undergraduate education. Canberra: Australian Government Publishing Services.

Carlson, P.J. \& Burke, F. 1998. Lessons learned from ethics in the classroom: Exploring student growth in flexibility, complexity and comprehension. Journal of Business Ethics, 17(11): 1179-1187.

Cavanaugh, S.H. 1993. Connecting education and practice. In L. Curry, \& J.F. Wergin and Associates (eds.) Educating professionals: Responding to new expectations for competence and accountability. San Francisco: Jossey Bass Publishers. pp. 107-125.

Clark, K.M. 1980. SDL: Rediscovery of an ancient art. In S.S. Cooper, \& M.C. Seal (eds.) Perspectives on continuing education in nursing. Pacific Palisades: NURSECO.

Cooper, D.R. \& Schindler, P.S. 2003. Business research methods (8th edition). New York: McGraw-Hill.

Cowton, C.J. \& Cummins, J. 2003. Teaching Business Ethics in UK Higher Education: Progress and prospects. Teaching Business Ethics, 7(1): 37-54.

Cragg, W. 1997. Teaching Business Ethics: The role of ethics in business and in business education. Journal of Business Ethics, 16(3): 231-245.

Dempsey, A. \& Stegmann, N. 2001. Accounting I: Attracting and retaining learners. Paper delivered at a conference of the South African Institute of Chartered Accountants on 31 October 2001.

Diller-Haas, A. 2004. Time to change introductory Accounting. The CPA Journal, 74(4): 60-62.
Els, G. 2007. Utilising continued professional development of ethics amongst prospective chartered accountants. Unpublished doctoral thesis. Johannesburg: University of Johannesburg.

Fischer, G. \& Scharff, E. 1998. Learning technologies in support of self-directed learning. Journal of Interactive Media in Education, 98(4).

Gibbs, G. 1992. Improving the quality of learning. Bristol: Technical and Education Services Ltd.

Grasso, L.P. \& Kaplan, S.E. 1998. Emphasis on ethics in tax education. In L. Ponemon, M.J. Epstein, J.C. Gaa \& R.G. Ruland (eds.) Research on Accounting Ethics, 4: 73-87. JAI Press Inc.

Grimstad, C.R. 1964. Teaching the ethics of accountancy. The Journal of Accountancy, 118: 82-85.

Hiltebeitel, K.M. \& Jones, S.K. 1991. Initial evidence on the impact of integrating ethics into accounting education. Issues in Accounting Education, 6: 262-275.

Houle, C.O. 1980. Continuing learning in the professions. San Francisco: Jossey Bass Publishers.

International Federation of Accountants (IFAC). 1998. Competence-based approaches to the professional preparation of accountants. New York: International Federation of Accountants.

International Federation of Accountants (IFAC). 2003a. International Education Standards for Professional Accountants, IES 1-6. New York: International Federation of Accountants.

International Federation of Accountants (IFAC). 2003b. International Education Paper, IEP 2: Towards competent professional accountants. New York: International Federation of Accountants.

International Federation of Accountants (IFAC). 2003c. Discussion paper: 2000 and beyond - a strategic framework for prequalification education for the accountancy profession in the year 2000 and beyond. New York: International Federation of Accountants.

International Federation of Accountants (IFAC). 2004. Continuing professional development: A program for lifelong learning and continuing development of professional competence. International Education Standard for Professional Accountants, IES 7. New York: International Federation of Accountants.

Josephs, M.J. 1978. A competency-based program. National Conference on Higher Education: Adapting institutions to the adult learner (experiments in progress). Washington, DC: American Association for Higher Education.

Kenny, S. \& Eining, M.M. 1996. An experimental investigation incorporating attribution theory. In $\mathrm{L}$. Ponemon, M.J. Epstein, J.C. Gaa \& R.G. Ruland (eds.) Research on Accounting Ethics, Volume 2: 73-86. JAI Press Inc.

Langenderfer, H.Q. \& Rockness, J.W. 1989. Integrating ethics into the accounting curriculum: Issues, problems, and solutions. Issues in Accounting Education, Spring: 58-59.

Loeb, S.E. \& Rockness, J. 1992. Accounting ethics and education: A response. Journal of Business Ethics, 11(7): 485-495.

Loeb, S.E. 1988 .Teaching students accounting ethics: Some crucial issues. Issues in Accounting Education, 3: 316-329. 
Loeb, S.E. 1990. Whistle blowing and accounting education. Issues in Accounting Education, 3: 281-294.

Lovell, A. 1992. Accounting education: A developing debate. Management Accounting, 70(3): 20-23.

Maclagan, P. 2002 Reflections on the integration of ethics teaching into a British undergraduate management degree programme. Teaching Business Ethics, 6(3): 297-318.

May, G.S., Windall, F.W. \& Sylvestre, J. 1995. The need for change in accounting education: An educator survey. Journal of Accounting Education, 13: 21-43.

Milne, M.J. \& McConnell, P.J. 2001. Problem-based learning: A pedagogy for using case material in accounting education. Accounting Education, 10(1): 61-82.

Myers, R. 2005. Accounting Education Changes Course. Journal of Accountancy, 200(4): 108-111.

Nelson, D.R. \& Wittmer, D.P. 2001. Developing a learning community approach to business ethics education. Teaching Business Ethics, 5(3): 267-281.

Nelson, I.T. 1995. What's new about accounting education change? An historical perspective on the change movement. Accounting Horizons, Fall: 62-75.

Person, S. 2002. Accounting education: Charting a course through a perilous future. Journal of Accountancy, 193(4): 84-85.

Prozesky, M. 2001. Ethics in the education of South African Chartered Accountants. Report prepared for the South African Institute of Chartered Accountants. Pietermaritzburg: Unilever Ethics Centre, University of Natal.

Shaub, M. 1991. An analysis of factors affecting the cognitive moral development of auditors and auditing students. Working Paper, University of Nebraska. College of Business Administration. Nebraska: University of Nebraska.

Sims, R.R. \& Brinkmann, J. 2003. Business ethics curriculum design: Suggestions and illustrations. Teaching Business Ethics, 7(1): 69-86.

Sims, R.R. 2002. Business ethics teaching for effective learning. Journal of Business Ethics, 6(4): 393-410.

South African Institute of Chartered Accountants, The (SAICA) 2005a. Competence and continued professional development. Johannesburg: The South African Institute of Chartered Accountants.
South African Institute of Chartered Accountants, The (SAICA) 2005b. Background and policy document on continuing professional development. Johannesburg: The South African Institute of Chartered Accountants.

St. Pierre, K.E., Nelson, E. \& Gabbin, A. 1990. A study of the ethical development of accounting majors in relation to other business and non-business disciplines. The Accounting Educators' Journal, Summer: 23-35.

Sundem, G.L., Williams, D.Z. \& Chironna, J.E. 1990. The revolution in accounting education. Management Accounting, 47(12): 49-53.

Uys, T. 2003. Measuring and quantifying. In D. Rossouw (ed.) Intellectual tools: Skills for the human sciences (2nd edition). Pretoria: Van Schaik Publishers. pp. 117-126.

Williams R.H., Zimmerman, D.W., Zumbo, B.D. \& Ross, D. 2003. Charles Spearman: British behavioral scientist. Human Nature Review, 3: 114-118.

Williams, B. 2001 The theoretical links between problembased learning and self-directed learning for continuing professional nursing education. Teaching in Higher Education, 6(1): 85-98.

Wright, G.B., Cullinan, C.P. \& Bline, D.M. 1998 Recognising ethical issues: The joint influence of ethical sensitivity and moral intensity. In L. Ponemon, M.J. Epstein, J.C. Gaa \& R.G. Ruland (eds.) Research on Accounting Ethics, Volume 4: 29-52. JAI Press Inc.

\section{Address correspondence to:}

Gideon Els

Department of Finance and Investment Management University of Johannesburg

PO Box 524 Auckland Park, 2006

Johannesburg, South Africa e-mail:gels@uj.ac.za 
Reproduced with permission of the copyright owner. Further reproduction prohibited without permission. 